\title{
ELEGANT, RAPID AND SIMPLE PROCEDURE FOR LABELING OF ANTIBODIES WITH FLUORESCENT ZnCd/S QUANTUM DOTS FOR LASER ABLATION ICP-MS DETECTION
}

\author{
1,2Navid ASSI, ${ }^{1,2}$ Kristyna PAVELICOVA, 1,2Marketa VACULOVICOVA, ${ }^{3}$ Tomas VACULOVIC \\ ${ }^{1}$ Department of Chemistry and Biochemistry, Mendel University in Brno, Brno, Czech Republic, EU, \\ navid.assi@vutbr.cz, marketa.ryvolova@seznam.cz, k.pavelicova@seznam.cz \\ ${ }^{2}$ Central European Institute of Technology, Brno University of Technology, Brno, Czech Republic, EU, \\ navid.assi@vutbr.cz, marketa.ryvolova@seznam.cz \\ ${ }^{3}$ Department of Chemistry, Masaryk University in Brno, Brno, Czech Republic, EU, \\ tomas.vaculovic@ceitec.muni.cz
}

https://doi.org/10.37904/nanocon.2020.3752

\begin{abstract}
Antibody labeling with a signal-providing tag (e.g. an enzyme, chromophore, fluorophore, metal chelate, radioisotope, etc.) is a key procedure in bioanalytical techniques such an enzyme-linked immunosorbent assay, western blot, or immunohistochemical analysis. The process may be laborious, impair the activity, and time-consuming. Concisely, in this work, an elegant method of rapid and effective antibody labeling by quantum dots was developed taking advantage of partial reduction of antibody structure and UV-induced quantum dot formation. Zinc and cadmium with the thiol group of the antibody as capping agents stabilizing the fluorescent nanoparticle while the biorecognition capabilities were maintained. The $\mathrm{ZnCd} / \mathrm{S}$ quantum dots creation has to prosper detected with capillary electrophoresis (CE) and laser ablation ICP- MS (LA- ICP-MS).
\end{abstract}

Keywords: Antibody, antigen, quantum dots, cleavage disulfide bonds, fluorescent

\section{INTRODUCTION}

Antibody labeling techniques are extremely an important tool for protein detection and it can be done by direct or indirect labeling. The disadvantage of the process may impair antibody activity with excessive labeling, steric hindrance, and alter activity for high molecular weight such as enzymes, discontinuity conjugation for multiple fluorophores and enzymes, laborious and time-consuming [1,2].

Quantum dots (QDs) are described as the most popular fluorescent inorganic nanoparticles (FINPs) which have properties such as good biocompatibility, stable photoluminescence, and narrow emission band. These materials attract attention in recent years and play a key role in a different field such as ion detection, biolabeling or bioimaging [3,4]. Antibodies are widely used as targeting moieties with QDs for specific cell labeling. They interact with the host cell and remain adhered to the surface or internalized by endocytosis [5]. The labeled antibody with quantum dots has been detected with laser ablation ICP-MS (LA-ICP-MS) for trace element determination [6] and capillary electrophoresis to verified the formation of QDs-antibody [7].

In this research work, for the first time, $\mathrm{ZnCd} / \mathrm{S}$ quantum dots prepared by UV-induced synthesis with partially reduced antibody as a capping agent were used for immunoanalysis with elemental analysis. UV irradiation duraion and metal ratio were optimized to achieve a high fluorescent intensity. To explore $\mathrm{ZnCd} / \mathrm{S}$ formation, LA-ICP-MS, and CE were used as superior instruments for quantum dots characterization. 


\section{MATERIALS AND METHODS}

\subsection{Materials}

Anti-mouse IgG H\&L (ab6708) was purchased from Abcam (Cambridge, UK). All chemicals and solutions used in this study provisioned daily without further purification were purchased from Sigma-Aldrich (St. Louis, MO, USA) in ACS purity. Millipore water was used throughout the experiment.

\subsection{Simultaneous QDs Synthesis and Antibody Conjugation Process}

Quantum dots-antibody (QDs-Ab) probe was prepared according to the simple modus operandi. In order to reduction of $1 \mathrm{mg} / \mathrm{mL}$ of the anti-mouse $\mathrm{lgG}$, tris(2-carboxyethyl) phosphine (TCEP) was used in the concentration of $25 \mathrm{mM}$ at $37^{\circ} \mathrm{C}$ for 90 min with sodium phosphate buffer $\left(\mathrm{Na}_{2} \mathrm{HPO}_{4} / \mathrm{NaH}_{2} \mathrm{PO}_{4}\right) \mathrm{pH}=7$ in a total volume of $10 \mu \mathrm{L}$. Precursors containing zinc acetate $\left(4 \times 10^{-5} \mathrm{mM}\right)$ and cadmium acetate $\left(6 \times 10^{-6} \mathrm{mM}\right)$ were mixed with reduced anti-mouse IgG in $100 \mu \mathrm{L}$ sodium phosphate buffer $\mathrm{pH}=7$. The prepared solution was pipetted into the UV-transparent 96-well plate (Corning, USA) and placed into the UV transilluminator (Vilber Lourmat, Marne-la-Vallee Cedex, France) with wavelength of $254 \mathrm{~nm}$. Resulting solution was analyzed by fluorescence spectrometry. Fluorescent intensity was measured in the range of 230 to $700 \mathrm{~nm}$ with Synergy $\mathrm{H} 1$ (BioTek, USA). Scheme 1 is illustrating the overall procedure.

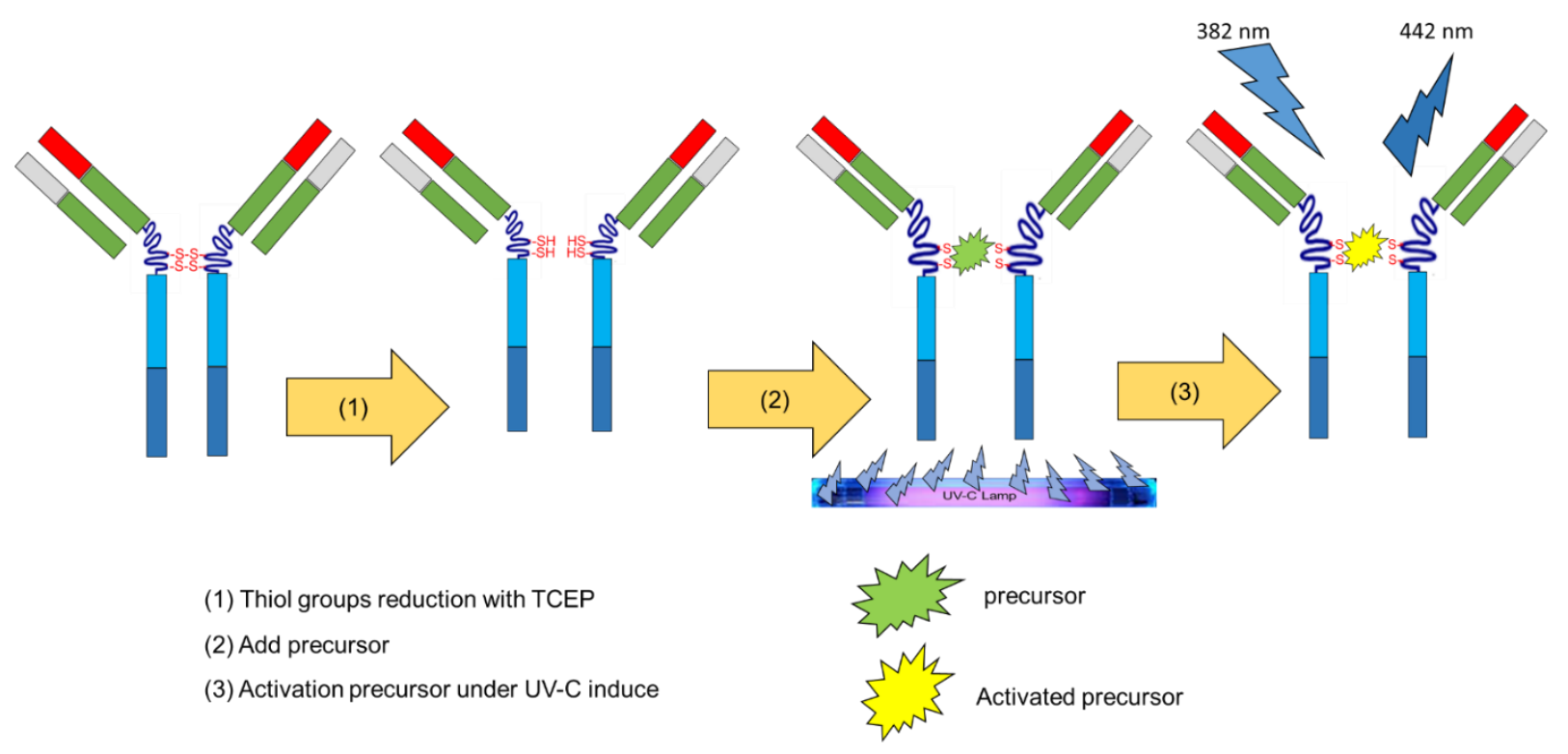

Scheme 1 Anti-mouse IgG reduction and creation of $\mathrm{ZnCd} / \mathrm{S}$ quantum dots with antibody conjugation

\subsection{Capillary electrophoresis (CE)}

Prepared QDs-Ab was analyzed by CE instrument 7100 (Agilent Technologies, Germany) with absorbance detection at a wavelength of $254 \mathrm{~nm}$. Fused silica capillary with an internal diameter of $75 \mu \mathrm{m}$, with a total length of $64.5 \mathrm{~cm}$, and an effective length of $56 \mathrm{~cm}$ was used. The samples were injected hydrodynamically by $50 \mathrm{mbar}$ applied for $6 \mathrm{~s}$ and the separation voltage was $20 \mathrm{kV}$. The background electrolyte (BGE) was composed with $20 \mathrm{mM}$ sodium borate buffer pH 9 for $120 \mathrm{~s}$. Between the injections, the capillary column was washed for 60 s using BGE.

\subsection{LA- ICP- MS Quantitative Mapping}

Qds-Ab formation was evaluated as describer earlier [8] by LA-ICP-MS setup consisting, LA system UP213 (NewWave Research, USA), emitting laser radiation with a wavelength of $213 \mathrm{~nm}$, the pulse width of $4.2 \mathrm{ns,}$ ablation flow of a He (1.0 l/min) into ICP-MS Agilent 7500CE (Agilent Technologies, Japan). 


\section{RESULT AND DISCUSSION}

\subsection{Effect of UV irradiation time and $\mathrm{Zn} / \mathrm{Cd}$ molar ratio}

It is comprehended that increasing the UV irradiation time and $\mathrm{Zn} / \mathrm{Cd}$ molar ratio would increase the yield of prepared QDs-Ab. Therefore, these parameters were evaluated. UV irradiation time had an important effect on the preparation $\mathrm{ZnCd} / \mathrm{S}$ quantum dots [9] which is illustrated in Figure 1 (A), the maximum fluorescent intensity was achieved at $442 \mathrm{~nm}$ under $382 \mathrm{~nm}$ excitation. The composition of $\mathrm{ZnCd} / \mathrm{S}$ quantum dots for obtaining higher fluorescent intensity was mainly dependent on the initial concentration of $\mathrm{Zn}$, $\mathrm{Cd}$, and the intrinsic reactivity of $\mathrm{Zn}$ and $\mathrm{Cd}$ toward S [10]. The QDs-Ab solution was prepared with the different molar ratios of $\mathrm{Zn} / \mathrm{Cd}(4,16,32$, and 64$)$ and the maximum emission was obtained in molar ratio 32 as shown in Figure 1 (B).
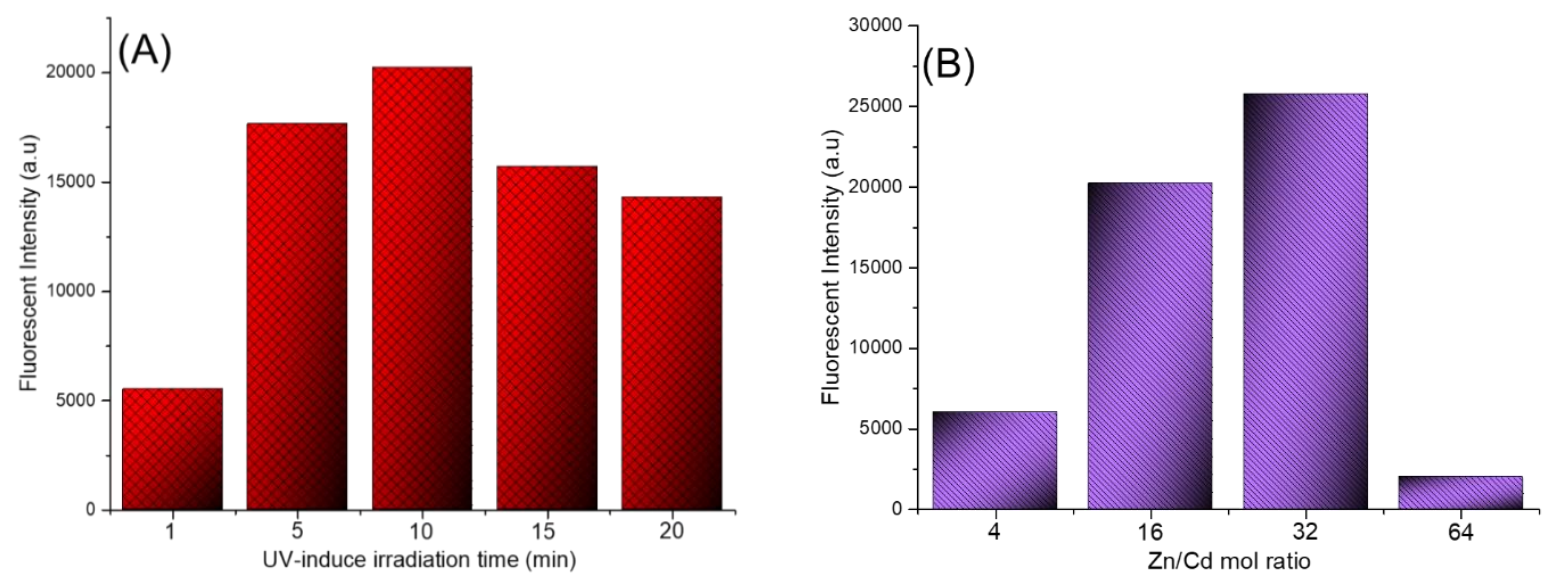

Figure 1 Effect of UV-induces irradiation time $(A)$ and $Z n / C d$ molar ratio on fluorescent intensity $(B)$

\subsection{CE and LA-ICP-MS analysis}

To reveal that QDs-Ab was formed, $C E$ is a valuable instrument [11]. Figure 2 (A) shows the electropherograms of anti-mouse IgG before and after reduction and anti-mouse lgG labeled by in situ synthesized QDs (QDs-Ab). In general, a peak in migration time 4.17 min belongs to electroosmotic flow (EOF). Firstly, the anti-mouse IgG was analyzed (blue trace) and a sharp peak appeared in the migration time of 6.65 min. Next, anti-mouse IgG after reduction exhibited slightly distorted peak (red trace) with migration time of 6.79 min. Eventually, the peak (green trace) with migration time, $6.96 \mathrm{~min}$ demonstrates that antimouse IgG was labeled $\mathrm{ZnCd} / \mathrm{S}$. The increased migration time suggests not only increasing size but also increasing negative charge of the QDs-Ab.

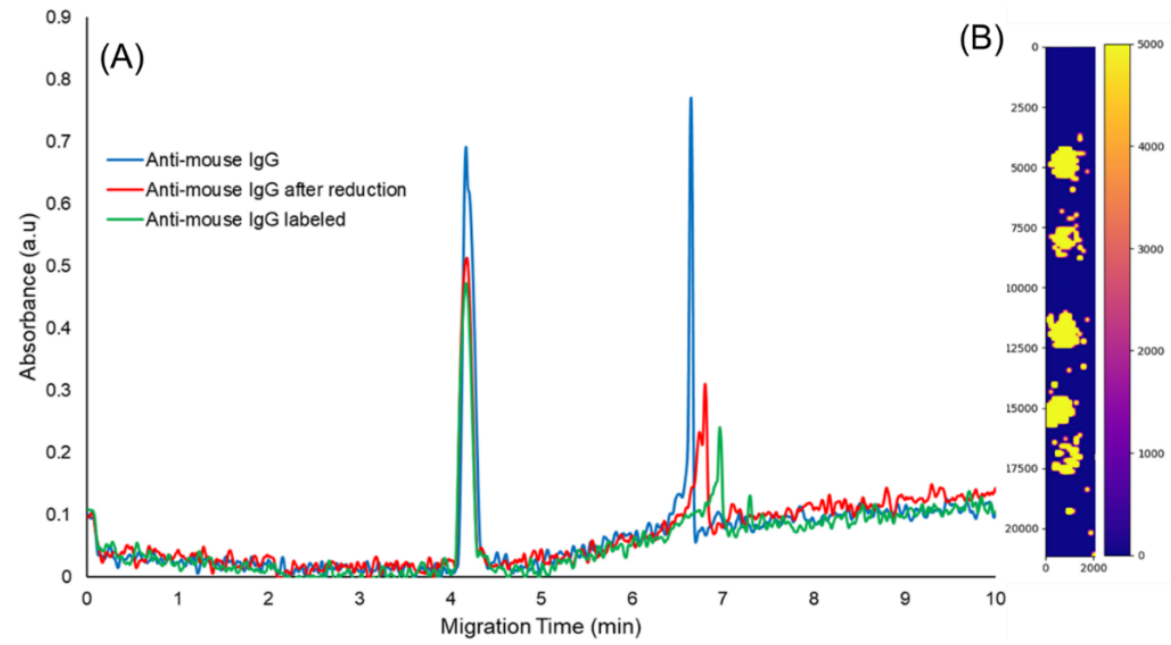

Figure 2 Electropherograms of anti-mouse lgG before and after reduction and anti-mouse $\lg G$ labeled with $\mathrm{ZnCd} / \mathrm{S}(\mathrm{A})$ and Cd analysis of QDs-Ab by LA-ICP-MS (B) 
LA-ICP-MS has been used for the determination of metals in purified QDs-Ab samples. As is illustrated in Figure 2 (B), five dots of QDs-Ab were detected in polyvinylidene difluoride (PVDF) membrane, with comparable intensity of $\mathrm{Cd}$.

\section{CONCLUSION}

Labeling anti-mouse IgG with in situ prepared $\mathrm{ZnCd} / \mathrm{S}$ quantum dots by utilizing antibody thiol groups as a stabilizer was accomplished for the first time. Simplicity, convenience and time-effectivness are the main benefits of this procedure for antibody labeling. Fluorescent intensity is the main sign of preparation quantum dots optimized based on UV irradiation time and precursor metals ratio. Antibodies labeled with quantum dots were analyzed by LA-ICP-MS and CE and will be used in the near future for immuno-based analysis (e.g. dot blot or ELISA).

\section{ACKNOWLEDGEMENTS}

\section{The research was founded by the Internal Grant Agency of Mendel University in Brno IGA MENDELU 2019_TP_009.}

\section{REFERENCES}

[1] ELLISMAN, M. H., DEERINCK, T. J., SHU, X., SOSINSKY, G. E. Chapter 8 - picking faces out of a crowd: Genetic labels for identification of proteins in correlated light and electron microscopy imaging. In: MÜLLER-REICHERT, T.; VERKADE P., eds. Methods in cell biology. Academic Press, 2012, vol 111.

[2] EKINS, R. Merits and disadvantages of different labels and methods of immunoassay. In: Immunoassays for the 80s. Springer, 1981.

[3] LIN, T.-Y., LIAN, Z.-J., YAO, C.-X., SUN, X.-Y., LIU, X.-Y., YAN, Z.-Y., WU, S.-M. Cdse quantum dots labeled staphylococcus aureus for research studies of thp-1 derived macrophage phagocytic behavior. RSC Advances. 2020, vol. 10. no. 1, pp. 260-270.

[4] NG, S. M., KONESWARAN, M., NARAYANASWAMY, R. A review on fluorescent inorganic nanoparticles for optical sensing applications. RSC Advances. 2016, vol. 6, no. 26, pp. 21624-21661.

[5] SAHOO, S. L., LIU, C.-H., KUMARI, M., WU, W.-C., WANG, C.-C. Biocompatible quantum dot-antibody conjugate for cell imaging, targeting and fluorometric immunoassay: Crosslinking, characterization and applications. RSC Advances. 2019, vol. 9, no. 56, pp. 32791-32803.

[6] HUTCHINSON, R. W., COX, A. G., MCLEOD, C. W., MARSHALL, P. S., HARPER, A., DAWSON, E. L., HOWLETT, D. R. Imaging and spatial distribution of $\beta$-amyloid peptide and metal ions in alzheimer's plaques by laser ablationinductively coupled plasma-mass spectrometry. Analytical Biochemistry. 2005, vol. 346. no. 2, pp. 225-233.

[7] STANISAVLJEVIC, M., VACULOVICOVA, M., KIZEK, R., ADAM, V. Capillary electrophoresis of quantum dots: Minireview. Electrophoresis. 2014, vol. 35. no. 14, pp. 1929-1937.

[8] VANECKOVA, T., BEZDEKOVA, J., TVRDONOVA, M., VLCNOVSKA, M., NOVOTNA, V., NEUMAN, J., STOSSOVA, A., KANICKY, V., ADAM, V., VACULOVICOVA, M. Cds quantum dots-based immunoassay combined with particle imprinted polymer technology and laser ablation icp-ms as a versatile tool for protein detection. Scientific reports. 2019, vol. 9. no. 1, pp. 1-9.

[9] NEJDL, L., ZEMANKOVA, K., HAVLIKOVA, M., BURESOVA, M., HYNEK, D., XHAXHIU, K., MRAVEC, F., MATOUSKOVA, M., ADAM, V., FERUS, M. Uv-induced nanoparticles-formation, properties and their potential role in origin of life. Nanomaterials. 2020, vol. 10. no. 8, pp. 1529.

[10] WANG, N.-X., WANG, Y.-Q., HE, X.-W., LI, W.-Y. One-step and rapid synthesis of composition-tunable and watersoluble zncds quantum dots. Journal of nanoscience and nanotechnology. 2011, vol. 11. no. 5, pp. 4039-4045.

[11] KLEPÁRNÍK, K., DATINSKÁ, V., VORÁČOVÁ, I., LIŠKOVÁ, M. Analysis of quantum dots and their conjugates by capillary electrophoresis with detection of laser-induced luminescence. Quantum dots: Applications in biology. Springer, 2014.

[12] MÜLLER, S. D., DIAZ-BONE, R. A., FELIX, J., GOEDECKE, W. Detection of specific proteins by laser ablation inductively coupled plasma mass spectrometry (la-icp-ms) using gold cluster labelled antibodies. Journal of Analytical Atomic Spectrometry. 2005, vol. 20. no. 9, pp. 907-911. 